\section{Media practices of young Australians: Tangible and measurable reflections on a digital divide}

\author{
KOME - An International Journal of Pure \\ Communication Inquiry \\ Volume 8 Issue 1, p. 80-96. \\ (C) The Author(s) 2020 \\ Reprints and Permission: \\ kome@komejournal.com \\ Published by the Hungarian Communication \\ Studies Association \\ DOI: $\underline{10.17646 / \text { KOME. } 75672.42}$
}

\title{
luke gaspard ${ }^{1}$, Heather Horst ${ }^{1}$, Edgar Gómez Cruz ${ }^{2}$ and Sarah Pink ${ }^{3}$ \\ ${ }^{1}$ Department of Media \& Communications, The University of Sydney, AUSTRALIA \\ ${ }^{2}$ School of the Arts \& Media, The University of New South Wales, AUSTRALIA \\ ${ }^{3}$ Monash Art, Design and Architecture, Monash University, AUSTRALIA
}

\begin{abstract}
This paper presents findings on the household availability of digital media devices and the uses made of this technology by young people aged 12 to 18 living within the Greater Melbourne area of Australia. Drawing upon questionnaire data from a purposive sample of 860 students frequency analysis of this data indicates three dominant factors shape a young person's media experience: gender, siblings present within the home, and parents' highest level of education ${ }^{1}$. Moreover, when examining the types of software programs and the social network services used by young people age emerges as an additional layer to understanding these practices. In order to help contextualise these digital engagements, a comparative analysis with youth in the UK and the USA is undertaken to explore the ongoing validity of previous research claiming Australian youth as being some of the most digitally connected youth in the world.
\end{abstract}

Keywords: Devices; Digital; Gradation; Software; Youth

\section{Introduction}

Access to the Internet is a ubiquitous feature of young peoples' lives in the developed world. Whether in the home, school, library, or public-spaces affording free Wi-Fi services, these connective possibilities can facilitate an enormous range of online-based activities, which even ten years before would be unimaginable. Alongside this exponential growth in access opportunities, the increased availability of cheap convergent digital technology expands the range of how, when, and where young people can go online.

As young people have encountered a literal and metaphorical withdrawal from public life due to issues of perceived safety, a lack of suitable public spaces and an increasingly protected socio-cultural status in society (Ariés, 1973; Buckingham, 2000; Qvortrup, 2009a \& b; et al., 2009), the Internet has emerged as a contemporary virtual playground. Online participation functions as a critical space for youth identity construction, communicative practices and social

\footnotetext{
${ }^{1}$ Research indicates completed level of education is an important deterimant to earning potential - better qualified people have higher incomes (ABS, 2017; OECD, 2019)

Address for Correspondence: luke gaspard, email: luke.gaspard.70@gmail.com

Conflict of Interest: The authors declare no conflicts of interest.

Article received on the 4th July, 2019. Article accepted on the 15th December, 2019.

Conflict of Interest: The authors declares no conflict of interest.
} 
relationships, and new forms of learning and literacies (e.g. boyd, 2008; Buckingham, 2007; Jenkins 2006 et al., 2009; Ito et al., 2010). This, rightly or wrongly has been coupled with broader perceptions framing youth as "digital natives" against adults as "digital immigrants", whereby it is assumed or proposed that young people possess greater competence than those providing, managing and shaping their online experiences (Palfrey \& Gasser, 2011; Tapscott, 2009) - positions challenged by several authors including David Buckingham (2008), Sonia Livingstone (2002) and Ellen Johanna Helsper and Rebecca Eynon (2013).

This paper presents findings from Australian data collected as part of a larger European Union Horizon 20/20 funded eight-nation research project entitled Transmedia Literacy: Exploiting transmedia skills and informal learning strategies to improve formal education. Analysing questionnaire data collected from young people living in Melbourne, Australia, patterns emerge to the types of media used and the types of activities engaged. Three distinct factors emerge as shaping the media engagement throughout this cohort: a participant's gender, whether they have siblings within the household and parents' highest level of education; while age and gender are also essential to understanding the types of software programs and the social network services (SNS) they use. In order to contextualise the practices of these Australian youth comparative analysis is performed against data from youth in the UK and USA over a similar period to examine the commonality and differences to media engagements of young people within the world's three principle Anglophone nations. Outside of government and state regulatory funded research bodies (i.e. the Australian Bureau of Statistics (ABS) and Australian Communications and Media Authority (ACMA)) findings presented here add to the limited body of work providing large-scale analysis to the media practices of Australian youth ${ }^{2}$. Similarly, this work adds to previous research, which establishes how the term gradation rather than divide better defines the digital media experience of youth (e.g. Livngstone \& Helsper, 2007).

\section{Convergent digital-technology and young people}

Young people are vociferous consumers of the Internet. In recent years the amount of time they dedicate to online use has increased exponentially. Recent figures from OFCOM (2017) in the UK point to almost 21 hours a week spent on Internet consumption; more than time spent watching TV, gaming or using a mobile phone. Young people also go online frequently. As reported by PEW Internet Research (Lenhart, 2015), 56\% of US 13 to 17 year-olds go online several times a day, while $24 \%$ use the Internet "almost constantly". Alongside this, the Internet takes on greater importance to the lives of youth as they age (ACMA, 2013) and this group are among the most prolific users of the Internet when compared to other demographic groups (ACMA, 2015).

Important arguments to understanding the increasingly online-centred lives of young people are the affordances provided by convergent digital technologies and opportunities offered for sociality, learning, and the pursuit of specialised-interests (e.g. boyd 2008; Jenkins 2006 et al., 2009; Ito et al., 2010). A feature of this digitally convergent landscape is how media consumption is increasingly network-based in contrast to the broadcast-centrism of the past, allowing for a diverse range of content providers to emerge into the marketplace (Jenkins, 2006). The creation of user-generated content (UGC) by individual users utilising affordable easy to manage and widely available creation and dissemination tools is key to understanding how this space functions (ibid.) Because of the fluidity within this media ecology, due to both

\footnotetext{
${ }^{2}$ An excellent example of large-scale sample work on Australian youths' media practices can be found in another European Union supported work, Risks and safety for Australian children on the internet (2011), authored by Leila Green and colleagues.
} 
the movement of content across multiple platforms but also to how users can seamlessly move across, and within these platforms, Henry Jenkins (2006) points to a fundamental shift in the relationship between production and consumption. Thus the once separate and distinct roles that existed between producer and audience within a broadcast-system are now blurred resulting in changes to how culture is said to circulate within this digital context (Jenkins et al., 2013).

It is via this democratisation of media production and media consumption where a new continuum is in place for those utilising digital media. As coined by Axel Bruns (2008), the term "produser" encapsulates the collaborative and ongoing relationship within this new circulatory cultural space. Where according to Jenkins (2006) authorship of culture occurs both via the reading and writing of media content.

However, if to borrow a phrase from Patricia Lange (in Jenkins, 2014), "not all digital youth [are] created equally". Extensive diversity is present in respect of the typology and depth of engagement young people experience. This variability in digital media engagement, in part, reflects long-established differences to the socio-cultural characteristics of households and their incorporation of ICTs (Morley \& Silverstone, 1990). Thus parental standpoints on the expected value of ICT purchases for "entertainment" versus "edutainment" influences thinking as to how digital technology should be brought into and included within the structure and organisational patterns of the home (Horst, 2010, 2012; Lally, 2002; Livingstone, 2002). Similarly, parental attitudes, knowledge, and skills can cultivate children's relationships toward the use of the Internet and online services (boyd \& Hargittai, 2013; Tripp, 2010), allowing for the implementation of particular value-systems toward their exploitation.

These soft, or as we term them non-material impediments to youth's digital engagement, materialise in several other respects. The work of gaspard (2015), Seiter (2005, 2008), and Buckingham and Willett (2006), all point to how knowledge and social relationships can act as essential determinants to technological exploitation and inclusion. Thus, sources of information, access to role models and social networks of support to draw upon for guidance and help, all determine the quality of a young person's online experience. Further complicating these issues, literacy levels can impede young peoples' ability to more fully exploit digital engagement (Buckingham \& Willlet, 2006; Seiter, 2005, 2008). boyd and Hargittai (2013) also demonstrate how parental background and income impacts parental concern and interest in how younger members of the household navigate networked technologies. Echoing similar sentiments Lynn Schofield Clark (2013) identifies young people within lower- and higher-class households enacting different ethics of observation toward parental attitudes and wishes toward utilisation of technology. Similarly, Lisa Tripp (2010) addresses how migrant parents in the USA express concern that their children will engage in "fun"-based activities over more "productive" school-based use of often-hard to find Internet opportunities.

However, there are more tangible and measurable reflections on a digital divide that frame the quality and ability of online participation a young person can experience within the context of the home. The socio-economic status of the household including income and the highest level of parental completed education, as well as the number of parents in the home, allied to a youths' age, gender and race and whether they have siblings, have all been identified as critical determinants of a media-rich home and the quality of Internet access young people enjoy (ABS, 2011; ACMA, No.3 2008; Hargittai, 2010; Livingstone, 2011; Livingstone \& Helsper, 2007).

This paper presents questionnaire findings as to how these more tangible determinates shape the digital media activities of young people living in Melbourne, Australia, and in so doing adds to a growing but limited body of work examining youth media practices in this country. 


\section{Methodology}

Collected data is from a purposive sample of 860 young people aged 12 to 18 attending five high-schools and one primary school in the Greater Melbourne region. Students completed questionnaires between August 2016 and May 2017. Frequency analysis is performed on this data to examine patterns of media use and engagement within this cohort. The research team administered a face-to-face six-page paper-and-pen questionnaire with young people at their school if present on the research teams' visit. Selection of these Australian schools reflected a diverse sample group based upon cultural and ethnic background as well as socio-economic contexts. One of the schools is private ${ }^{3}$ and fee-paying; all others are public state schools. Located in the outer-suburban areas of Melbourne approximately thirty kilometres from the city's CBD, two schools lay to the west of the city and two to the east. Of the two remaining schools, both are within the city's inner zone. Questionnaire administration took place with individual classes of no more than 25 students. The questionnaire consisted of check-box responses related to demographic information and types of media available and used within the home, followed by questions as to the use of software programs and social networks. Throughout the remainder of the questionnaire, a five-point Likert scale was utilised to allow respondents to reflect upon engagement and perceptions of different media uses.

Once a school's students completed all its questionnaires data was keyed into an Excel spreadsheet for analysis. Further details of the project's methodology and dissemination materials are accessible at www.transmedialiteracy.org. This paper focuses upon frequency analysis conducted on the media practices of Australian youths. In the execution of this work, there is as per university guidelines adherence to all relevant ethic procedures and collection of relevant permissions

In total, 860 young people completed a questionnaire. Twenty-two of these, due to students not marking their age or gender or falling beyond the age-scope of the study, i.e. 11 or 19, are not included in final data analysis. From the remaining sample of 838 respondents, 497 are male, and 341 are female ${ }^{4}$. The following table (Table 1) details the number of students falling into each of the differing age-bands:

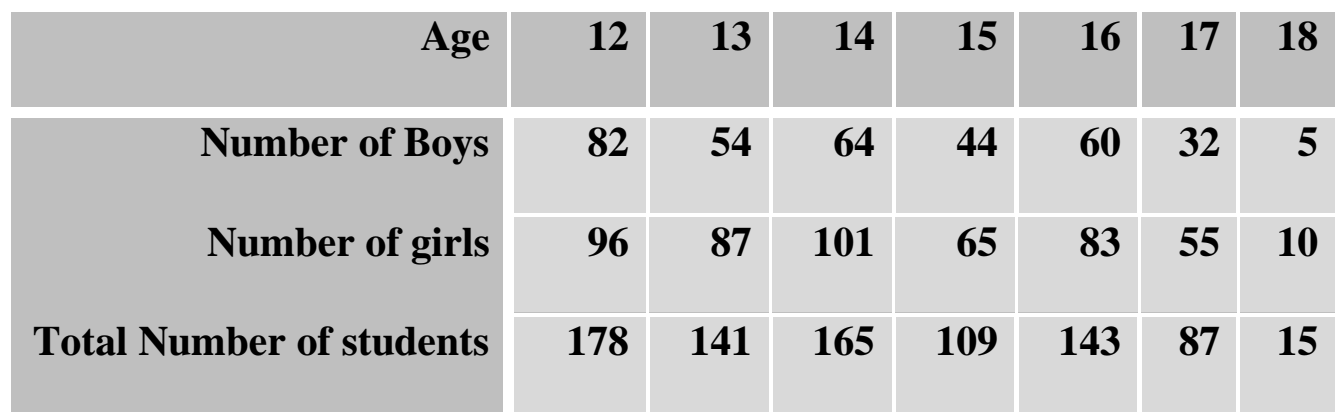

Table 1: Breakdown of participants by age

\footnotetext{
${ }^{3}$ In Australia, private schools in addition to receiving funding from school fees and private income receive additional revenue from Government and Commonwealth sources (see Hanrahan, 2017 for further discussion).

${ }^{4}$ While school enrollments in the state of Victoria have historically been gender heavy in favour boys (Victoria State Government, 2019), three of the schools sampled in this study have substantially higher numbers of enrolled boys than girls. The differences in the number of boys and girls completing a questionnaire for this study is simply reflective of the student population present on the day of the questionnaire administration.
} 


\section{Findings}

\section{Technology in the home}

A key concern of this research was to understand the degree of access to technology a young person experienced in their home. Of the thirteen specific devices asked if present, the mobile phone emerges as the most vital form of technology present in the homes of youth. As shown in Table 2, amongst these students, 97\% have access to mobile phones, more than have access to a wireless connection and even overtaking the TV as the most common piece of household technology. The average young person in this study has access to ten pieces of technology.

By and large, any gendered patterns to technological availability do not in the main appear as significant across the sample. Many pieces of technology emerge in near-identical numbers within the homes of boys and girls: laptops, mobile phones, tablets, TVs and Wi-Fi. Boys and girls also tend to have access to a similar number of devices: 9.9 for boys and 9.6 for girls. There is however two forms of technology appearing as particularly gendered, as they either appear more frequently in the homes of boys or the homes of girls: technology for gaming and specialised technology for consuming media content. Gaming devices, namely handheld or gaming consoles, appear more frequently in the homes of boys (46\% and $81 \%)$ than in the homes of girls $(33 \%$ and $70 \%$ ). There are, however, caveats to the gendering of these technologies as boys and girls age. While the level of access to handheld gaming devices decreases as boys and girls age, the opposite occurs in respect of game consoles. From the data we see among younger people aged 12 to $1510 \%$, more boys have access to gaming consoles than girls, whereas when aged 15 to 18 , this difference increases to $23 \%$.

In contrast, girls have greater access to technology whose specific purpose is to either listen or view media content: 7\% more MP3 /4 players are found in the homes of girls when compared to boys while $10 \%$ more radios are present in those same homes.

Although gender does not appear as a particularly significant qualifier to the number and range of devices a young person has access to within the home, two other essential characteristics frame the media-richness of a youths' household: namely whether the household contains multiple children and the highest completed level of parental education.

In those multiple-child households, of the pieces of technology questioned ten of thirteen devices (DVD player, desktop computer, tablet, handheld games device, photo camera, radio and video camera) are found more in these homes than single-child homes. Only laptops, MP3 / 4 players and mobile phones emerge as present in higher numbers when a participant does not have a sibling within the home. However, the increased frequency at which these three devices appears in these single-child households does not appear as particularly significant, between $1 \%$ and $3 \%$.

Similarly, in those households where parents have completed a higher education qualification, ten of thirteen pieces of technology are found in higher numbers than in homes where this is not the case. The following devices each appear as being most sensitive to this qualifier as they are found more in these types of homes: photo cameras, tablets, video cameras, DVD players, MP3/4 players and radios. Conversely in homes described as less educated a handheld games console is the only device significantly more present. 


\begin{tabular}{|c|c|c|c|c|c|c|c|c|c|c|c|}
\hline \multirow[b]{3}{*}{ Technology } & \multirow{3}{*}{$\begin{array}{l}\text { All } \\
\text { young } \\
\text { people } \\
\text { [N=838] }\end{array}$} & \multirow{3}{*}{$\begin{array}{l}\text { All boys } \\
{[\mathrm{N}=838]}\end{array}$} & \multirow{3}{*}{$\begin{array}{l}\text { All girls } \\
{[\mathrm{N}=\mathbf{8 3 8}]}\end{array}$} & \multicolumn{2}{|c|}{ Boys } & \multicolumn{2}{|c|}{ Girls } & \multirow{3}{*}{$\begin{array}{l}\text { With } \\
\text { sibling } \\
{[\mathrm{N}=666]}\end{array}$} & \multirow{3}{*}{$\begin{array}{l}\text { Without } \\
\text { sibling } \\
\text { [N=170] }\end{array}$} & \multirow{3}{*}{$\begin{array}{l}\text { No Higher } \\
\text { education } \\
\text { [N=267] }\end{array}$} & \multirow{3}{*}{$\begin{array}{l}\text { Higher } \\
\text { education } \\
{[\mathrm{N}=470]}\end{array}$} \\
\hline & & & & 12 to 14 & 15 to 18 & 12 to 14 & 15 to 18 & & & & \\
\hline & & & & {$[\mathrm{N}=284]$} & {$[\mathrm{N}=\mathbf{2 1 3}]$} & {$[\mathrm{N}=\mathbf{2 0 0}]$} & {$[N=141]$} & & & & \\
\hline TV & $96 \%$ & $96 \%$ & $95 \%$ & $96 \%$ & $95 \%$ & $95 \%$ & $96 \%$ & $96 \%$ & $94 \%$ & $95 \%$ & $96 \%$ \\
\hline DVD & $75 \%$ & $76 \%$ & $72 \%$ & $81 \%$ & $70 \%$ & $77 \%$ & $66 \%$ & $76 \%$ & $72 \%$ & $70 \%$ & $78 \%$ \\
\hline MP3 / MP4 etc. & $57 \%$ & $56 \%$ & $60 \%$ & $54 \%$ & $58 \%$ & $65 \%$ & $52 \%$ & $57 \%$ & $58 \%$ & $50 \%$ & $62 \%$ \\
\hline Desktop & $67 \%$ & $68 \%$ & $65 \%$ & $66 \%$ & $71 \%$ & $70 \%$ & $58 \%$ & $68 \%$ & $62 \%$ & $67 \%$ & $68 \%$ \\
\hline Laptop & $95 \%$ & $94 \%$ & $95 \%$ & $94 \%$ & $94 \%$ & $95 \%$ & $94 \%$ & $94 \%$ & $96 \%$ & $93 \%$ & $96 \%$ \\
\hline Tablet & $74 \%$ & $74 \%$ & $73 \%$ & $78 \%$ & $70 \%$ & $77 \%$ & $68 \%$ & $75 \%$ & $70 \%$ & $69 \%$ & $76 \%$ \\
\hline Wi-Fi & $95 \%$ & $96 \%$ & $95 \%$ & $96 \%$ & $95 \%$ & $95 \%$ & $96 \%$ & $96 \%$ & $95 \%$ & $96 \%$ & $95 \%$ \\
\hline Handheld game & $41 \%$ & $46 \%$ & $33 \%$ & $45 \%$ & $47 \%$ & $31 \%$ & $37 \%$ & $42 \%$ & $37 \%$ & $44 \%$ & $39 \%$ \\
\hline Home game & $76 \%$ & $81 \%$ & $70 \%$ & $81 \%$ & $82 \%$ & $73 \%$ & $65 \%$ & $81 \%$ & $61 \%$ & $75 \%$ & $76 \%$ \\
\hline Video camera & $66 \%$ & $68 \%$ & $62 \%$ & $71 \%$ & $64 \%$ & $68 \%$ & $55 \%$ & $69 \%$ & $53 \%$ & $60 \%$ & $68 \%$ \\
\hline Photo camera & $77 \%$ & $76 \%$ & $78 \%$ & $77 \%$ & $76 \%$ & $83 \%$ & $72 \%$ & $79 \%$ & $70 \%$ & $74 \%$ & $79 \%$ \\
\hline Radio & $62 \%$ & $59 \%$ & $65 \%$ & $65 \%$ & $51 \%$ & $69 \%$ & $61 \%$ & $64 \%$ & $54 \%$ & $55 \%$ & $67 \%$ \\
\hline Mobile phone & $97 \%$ & $96 \%$ & $97 \%$ & $100 \%$ & $100 \%$ & $97 \%$ & $97 \%$ & $96 \%$ & $99 \%$ & $97 \%$ & $97 \%$ \\
\hline
\end{tabular}




\section{Uses of software programs}

To further contextualise the technologically mediated lives of young people, the questionnaire asked students to record the types of ICT software programs they used. However, where we see the types of technology a young person has access to in the home as not particularly gendered dependent, the software programs and social network services they use does appear to be so. Although survey results here do reflect both quantitative and qualitative findings elsewhere indicating gendered uses of technology (e.g. Kasesniemi \& Rautiainen 2002; Puro 2002; Silverstone et al. 1994; Süss et al. 2001; Tufte \& Rasmussen 2010), results from participants in this study do not allow for any simple demarcation to the differing ways boys and girls use technology.

Among the Australian young people of this study, significant gendered differences are present to the types of software programs used. Girls prefer the use of media tools, facilitating creative expressive practices while boys favour more technically oriented software. For girls, programs related to the media making practices of drawing, web-blog editing, writing and music creation are more frequently mentioned by girls whereas software with a heightened technical component, i.e. video-editing and software coding, appear as more prevalent with the boys of this study (Table 3 ).

\begin{tabular}{|c|c|c|c|c|c|c|c|c|c|}
\hline & \multirow{2}{*}{$\begin{array}{l}\text { All } \\
\text { pupils }\end{array}$} & \multirow[t]{2}{*}{ Boys } & \multirow[t]{2}{*}{ Girls } & \multicolumn{2}{|c|}{ Boys } & \multicolumn{2}{|c|}{ Girls } & \multirow{2}{*}{$\begin{array}{l}\text { With } \\
\text { siblings }\end{array}$} & \multirow{2}{*}{$\begin{array}{l}\text { Without } \\
\text { siblings }\end{array}$} \\
\hline & & & & 12 to 14 & 15 to 18 & 12 to 14 & 15 to 18 & & \\
\hline Software program & {$[\mathrm{N}=\mathbf{8 3 8}]$} & {$[N=497]$} & {$[N=341]$} & {$[N=284]$} & {$[\mathrm{N}=\mathbf{2 1 3}]$} & {$[\mathrm{N}=\mathbf{2 0 0}]$} & {$[N=141]$} & {$[\mathrm{N}=666]$} & {$[\mathrm{N}=169]$} \\
\hline Word processor & $79 \%$ & $79 \%$ & $79 \%$ & $72 \%$ & $89 \%$ & $75 \%$ & $85 \%$ & $79 \%$ & $80 \%$ \\
\hline Photo editing & $28 \%$ & $24 \%$ & $34 \%$ & $20 \%$ & $29 \%$ & $38 \%$ & $28 \%$ & $28 \%$ & $28 \%$ \\
\hline Video editing & $17 \%$ & $19 \%$ & $13 \%$ & $15 \%$ & $24 \%$ & $16 \%$ & $11 \%$ & $17 \%$ & $17 \%$ \\
\hline Web blog editing & $17 \%$ & $16 \%$ & $17 \%$ & $14 \%$ & $20 \%$ & $16 \%$ & $20 \%$ & $16 \%$ & $20 \%$ \\
\hline Drawing & $16 \%$ & $13 \%$ & $20 \%$ & $14 \%$ & $11 \%$ & $23 \%$ & $16 \%$ & $16 \%$ & $15 \%$ \\
\hline Music creation & $19 \%$ & $18 \%$ & $22 \%$ & $19 \%$ & $15 \%$ & $26 \%$ & $18 \%$ & $18 \%$ & $23 \%$ \\
\hline Coding & $6 \%$ & $8 \%$ & $2 \%$ & $10 \%$ & $7 \%$ & $2 \%$ & $3 \%$ & $5 \%$ & $8 \%$ \\
\hline $\begin{array}{l}\text { Writing } \\
\text { screenwriting / } \\
\text { Wattpad }\end{array}$ & $13 \%$ & $7 \%$ & $22 \%$ & $7 \%$ & $6 \%$ & $21 \%$ & $23 \%$ & $12 \%$ & $17 \%$ \\
\hline
\end{tabular}

These gender differences, although broadly consistent as youth age, are most pronounced when aged 12 to 14. Although older boys do increase their interest in some software programs, a narrowing of these gendered differences is primarily due to girls no longer using these forms of software in the numbers they did when younger. Of the five creative expressive tools questioned about older girls are using two of these, drawing and music creation programs, at lower frequency rates than younger girls. While higher numbers of older girls are using creative writing software, the most significant differences between girls at these ages is in use of webblog editing software but most notably word-processing software. 
Like girls of this study, boys also demonstrate similarly non-uniform patterns to their use of software programs as they age. Older boys identify four of the eight pieces of software as more frequently used than younger boys: web-blog editing, video and photo editing, with wordprocessing representing the most significant difference. Only two of these programs are used more by both older boys and older girls: word-processing and web-blog editing software. The increased use of word-processing by young people within this age-group can likely be explained by how digital technology increasingly plays a part in the completion of homework tasks as youth age (Rideout, 2015, p. 82).

\section{Social media engagement}

There is, however, other forms of media use where age acts as a particularly strong signifier to use. Irrespective of gender, social network services (SNS) (Table 4) are used in more significant numbers by older youth compared to younger. Facebook is the service with the most significant increase in use between the differing age-groups (12 to $14 \& 15$ to 18 ) whereby older boys and older girls mention the use of the platform twice and three times respectively more than younger youth. This platform is also the only one of the four mentioned used more by boys than girls. Girls, in contrast, are much more heavily engaged in the use of the more visually-based platforms, Instagram and Snapchat. Across the whole of the sample, 26\% more girls favour the use of Instagram while 37\% more favour Snapchat when compared to boys. What is remarkable in the use of these two social media platforms is how much these tools are present in the lives of young girls, irrespective of age. At least seven out of every ten girls of this study are using either Instagram or Snapchat.

\begin{tabular}{|c|c|c|c|c|c|c|c|c|c|}
\hline \multirow[b]{3}{*}{ SNS } & \multirow{3}{*}{$\begin{array}{l}\text { All } \\
\text { young } \\
\text { people } \\
\text { [N=838] }\end{array}$} & \multirow{3}{*}{$\begin{array}{l}\text { Boys } \\
{[\mathrm{N}=497]}\end{array}$} & \multirow{3}{*}{$\begin{array}{l}\text { Girls } \\
\text { [N=341] }\end{array}$} & \multicolumn{2}{|c|}{ Boys } & \multicolumn{2}{|c|}{ Girls } & \multirow{3}{*}{$\begin{array}{l}\text { With } \\
\text { siblings } \\
{[\mathrm{N}=666]}\end{array}$} & \multirow{3}{*}{$\begin{array}{l}\text { Without } \\
\text { siblings } \\
\text { [N=169] }\end{array}$} \\
\hline & & & & 12 to 14 & 15 to & 12 to 14 & 15 to 18 & & \\
\hline & & & & {$[\mathrm{N}=284]$} & {$[\mathrm{N}=213]$} & {$[\mathrm{N}=\mathbf{2 0 0}]$} & {$[\mathrm{N}=141]$} & & \\
\hline Facebook & $52 \%$ & $54 \%$ & $49 \%$ & $34 \%$ & $82 \%$ & $26 \%$ & $82 \%$ & $50 \%$ & $60 \%$ \\
\hline Twitter & $16 \%$ & $16 \%$ & $17 \%$ & $15 \%$ & $17 \%$ & $14 \%$ & $21 \%$ & $15 \%$ & $21 \%$ \\
\hline Instagram & $70 \%$ & $62 \%$ & $81 \%$ & $57 \%$ & $68 \%$ & $81 \%$ & $82 \%$ & $68 \%$ & $75 \%$ \\
\hline Snapchat & $63 \%$ & $53 \%$ & $77 \%$ & $43 \%$ & $66 \%$ & $71 \%$ & $87 \%$ & $62 \%$ & $63 \%$ \\
\hline
\end{tabular}

At these rates of use, social media emerges as the pre-eminent way in which young people utilise technology. This is further reinforced, especially among older youth, when participants respond to questions asking which offline or online activity, they make the most use of on an every-day basis. When aged 12 to 14 one in six records using SNS "Every-day", whereas threequarters of 15 to 18 -year-olds do so over this period.

Unlike how the presence of siblings is important to the availability of technology within the home, households constructed in this way are not a factor to the software tools participants make use. If considering software programs or social media platforms, the level of youth engagement with either is independent of having a sibling in the home. 


\section{Offline and online media}

Clear amongst student participants is how offline media rarely figures in their daily lives. A revelation even starker among older participants, indicating that in many respects, older forms of media are obsolete in the lives of many young people. Listening to the radio, playing board games, reading comics and paper-based magazines or newspapers are all activities where the overwhelming majority of young people respond "Never" to spending time with these activities. The analysis also reveals these activities, alongside reading, is less relevant to older youth than younger youth. More participants aged 15 to 18 mentions "Never" participating in these media activities while fewer older youth record this as an "Every-day" practice when compared to young people aged 12 to 14 .

This same pattern of age-cohort difference is further present across the majority of media activities youth participate. Only two, accessing films and TV series online and use of social media are the only forms of media engagement older youth utilise more frequently than younger youth. Taken in conjunction with other research (e.g. Rideout, 2015; OFCOM, 2017) these findings further reinforce the centrality of digital technology and the Internet as the central focus for the media practices of contemporary youth, especially as they age.

As with social media and the presence of a small number of media devices in the home, reading is another activity displaying gendered patterns of use. Amongst these Australian girls, they are more likely to be avid readers, as $31 \%$ record doing so "Every-day" compared to $24 \%$ of boys, while $13 \%$ of boys claim to have "Never" read a book against $8 \%$ of girls.

\section{Content creation}

Further considering how youth exploit digital technology, questionnaires asked for responses regarding specific media-making practices. Apparent from analysis of this data is how more "active" creative forms of media use are not significant to the digital lives of these students. Whether utilising media tools in the creation of video content uploaded to the Internet, or the production of fan-fiction texts and stories, games or tutorials, between $51 \%$ and $71 \%$ of survey respondents record "Never" engaging with any of these practices (Table 5). There are, however, subtle differences to the types of media productions girls and boys participate. Boys more than girls engage with the practices of making and uploading video content to the Internet as well as making stories, games and tutorials. While more girls indicate making video content with a friend and the creation of fan-fiction of a favoured media text "At least twice a week" and "Every-day.

Despite the increased time older youth spend with digital media as already discussed, this does not translate, however, to greater engagement with creative media practices. Of the four practices discussed in this section, only two, making fan-fiction and the creation of stories games and tutorials, are carried out more frequently by older youth than younger youth during a month. 


\begin{tabular}{|c|c|c|c|c|c|}
\hline \multicolumn{3}{|c|}{$\begin{array}{l}\text { When I go to a friend's home, we } \\
\text { make a video }\end{array}$} & \multicolumn{3}{|c|}{$\begin{array}{l}\text { I like to make videos and upload } \\
\text { them to the Internet }\end{array}$} \\
\hline & $\begin{array}{r}\text { Boys } \\
{[\mathrm{N}=497]}\end{array}$ & $\begin{array}{r}\text { Girls } \\
{[\mathrm{N}=341]}\end{array}$ & & $\begin{array}{r}\text { Boys } \\
{[\mathrm{N}=497]}\end{array}$ & $\begin{array}{r}\text { Girls } \\
{[\mathrm{N}=341]}\end{array}$ \\
\hline Never & $55 \%$ & $48 \%$ & Never & $67 \%$ & $75 \%$ \\
\hline $\begin{array}{l}\text { Less than twice } \\
\text { a month }\end{array}$ & $22 \%$ & $23 \%$ & $\begin{array}{l}\text { Less than twice } \\
\text { a month }\end{array}$ & $14 \%$ & $12 \%$ \\
\hline $\begin{array}{l}\text { At least twice a } \\
\text { month }\end{array}$ & $13 \%$ & $13 \%$ & $\begin{array}{l}\text { At least twice a } \\
\text { month }\end{array}$ & $7 \%$ & $7 \%$ \\
\hline $\begin{array}{l}\text { At least twice a } \\
\text { week }\end{array}$ & $6 \%$ & $9 \%$ & $\begin{array}{l}\text { At least twice a } \\
\text { week }\end{array}$ & $6 \%$ & $3 \%$ \\
\hline Everyday & $3 \%$ & $7 \%$ & Everyday & $5 \%$ & $3 \%$ \\
\hline \multicolumn{3}{|c|}{$\begin{array}{l}\text { I like to make fan-fiction of my } \\
\text { favourite series, movies and comics }\end{array}$} & \multicolumn{3}{|c|}{$\begin{array}{l}\text { I like to create stories, create games, } \\
\text { make tutorials }\end{array}$} \\
\hline & $\begin{array}{r}\text { Boys } \\
{[\mathrm{N}=496]}\end{array}$ & $\begin{array}{r}\text { Girls } \\
{[\mathrm{N}=341]}\end{array}$ & & $\begin{array}{r}\text { Boys } \\
{[\mathrm{N}=497]}\end{array}$ & $\begin{array}{r}\text { Girls } \\
{[\mathrm{N}=341]}\end{array}$ \\
\hline Never & $73 \%$ & $66 \%$ & Never & $52 \%$ & $56 \%$ \\
\hline $\begin{array}{l}\text { Less than twice } \\
\text { a month }\end{array}$ & $11 \%$ & $13 \%$ & $\begin{array}{l}\text { Less than twice } \\
\text { a month }\end{array}$ & $19 \%$ & $18 \%$ \\
\hline $\begin{array}{l}\text { At least twice a } \\
\text { month }\end{array}$ & $10 \%$ & $9 \%$ & $\begin{array}{l}\text { At least twice a } \\
\text { month }\end{array}$ & $12 \%$ & $13 \%$ \\
\hline $\begin{array}{l}\text { At least twice a } \\
\text { week }\end{array}$ & $3 \%$ & $5 \%$ & $\begin{array}{l}\text { At least twice a } \\
\text { week }\end{array}$ & $8 \%$ & $6 \%$ \\
\hline /Everyday & $2 \%$ & $6 \%$ & Everyday & $9 \%$ & $6 \%$ \\
\hline
\end{tabular}




\section{Comparative media use}

Electronic media is ubiquitous to the everyday media practices of many young people, particularly those of the worlds' principle Anglo-nations, namely Australia, the United Kingdom and the United States of America. However, despite any socio-cultural and economic characteristics shared by these countries, irrespective of the many similarities present in the digitally mediated lives of youth, tangible differences also exist. To contextualise the mediaengagement of the 838 Australian young people of this study contemporaneous empirical work carried out in the UK and in the US by Common Sense Media (Rideout, 2015) and PEW Internet Research (Lenhart, 2015) provide comparable data to these youths' media practices.

Utilising available comparable age-group data from the UK (12 to 18 year-olds) and the US (13 to 18 year-olds), these Australian youth possess in higher numbers mobile computing technology most likely to facilitate access to the Internet. As seen in Table 6, Australian students of this study possess higher numbers of laptops and tablet devices than British and American young people.

\begin{tabular}{|c|c|c|c|}
\hline Device & $\begin{array}{l}\text { Australia } \\
\text { (12-18-year-olds) }\end{array}$ & $\begin{array}{l}\text { UK } \\
\text { (12-18-year-olds) }\end{array}$ & $\begin{array}{l}\text { USA } \\
\text { (13-18-year-olds) }\end{array}$ \\
\hline Tablet & $74 \%$ & $70 \%$ & $73 \%$ \\
\hline Desktop computer & $67 \%$ & $88 \% *$ & $63 \%$ \\
\hline Laptop & $95 \%$ & - & $77 \%$ \\
\hline Video game console & $76 \%$ & $65 \%$ & $83 \%$ \\
\hline $\begin{array}{l}\text { Handheld game } \\
\text { console }\end{array}$ & $41 \%$ & - & $45 \%$ \\
\hline
\end{tabular}

In contrast, gaming technology is much more prevalent in the homes of American youths indicating the likely importance of these forms of ICTs in the fabric of households within the respective countries. Further reinforcement of this is found when examining reporting as to how under $18 \mathrm{~s}$ in the USA are a more substantial proportion of the overall gaming population (28\%) (Statista.com, 2018) than youth gamers in Australia (23\%) (Brand et al., 2017) and in the UK (22\%) (Stastica.com, 2019b).

If to question why more mobile Internet-ready devices are present in the homes of these Australian young people when compared to their UK and American counterparts, the examination of education policy within these countries may help to shed some light.

For some time throughout the industrialised West, a significant focus has been to prepare future generations with the requisite digital tools to be ready for participation within a $21^{\text {st }}$ century work-force. The significantly contrasting approaches to meet such demands between the three countries have unsurprisingly produced different outcomes.

Australia, it can be argued, in comparison to the UK and USA, has enacted the most systematic approach to equipping its students with digital technology. In comparison, 
Education policies in the USA and Britain can both be described at best ad-hoc and fragmentary. In Australia as first laid out in the government-backed Digital Education Reform (DER) 2008 subsequently followed by Bring-Your-Own-Device (BYOD) initiatives provided for at state levels ongoing commitments have been in place for the provision of one-to-one $(1: 1)$ computing technology for students at both the high-school and primary levels. US schools in contrast due to the regulatory structure of education whereby local districts or individual states are responsible for the implementation of policy, wide discrepancies exist to meeting these technological demands. As such large numbers of school district administrators (35\%) remain reticent toward students using their technology in the classroom with very few (15\%) believing they have sufficient Internet connectivity to meet demand (Project Tomorrow, 2013). Reinforcing how issues of school network capacity impede computing take-up in the US research provided by IT solutions provider, Insight, provides a further clue. According to the company's whitepaper, Fine-Tuning Critical Infrastructures in the Age of Common Core and Online Assessments (2015), "75\% of U.S. schools do not have the appropriate network bandwidth to support one-to-one computing initiatives." Likewise, the UK's approach to computing technology within schools has and continues to be defined by a failure to have a joined-up forward-looking perspective. In the 1980s with the first introduction of computers to British classrooms education policy allowed domestically-produced computer systems to dominate the school market while other forms of non-compatible windows-based technology achieved wider traction throughout the business world and within the much larger US school system (McKinsey \& Company, 1997). More recently, a market-driven choice-based approach, which allows individual UK schools to determine how and where technology budget expenditure occurs has resulted in a considerable discrepancy between how different groups within schools perceive technology provisions. In research conducted by Promethean World (2016), a global technology solutions provider for schools, while headteachers universally agreed resources are adequately "allocated to technology" almost seven of ten teachers believe technology budget resources are inadequate or invested inappropriately. Further research, carried out by The British Educational Suppliers Association (INNOVA, 2015), would appear to support the outlooks' of teachers over that of headteachers. In findings from 632 respondents with some if not all the responsibility for ICT decisions working in primary and secondary schools, "34\% of schools believe their current implementation of tablets in the classroom is poor", and just over half (52\%) responded they possessed sufficient Wi-Fi capacity to support tablet use.

The success of the Australian approach against that of the UK and USA can it argued be recognised in reporting pointing to the level of computing technology available to school students around the world. According to the OECD, Australia has the fewest students per computer in all countries (0.9) compared to 1.4 in the UK and 1.8 in the USA (2015, p. 20).

\section{Social media}

Where online communication tools such as social media are recognised as valuable for young people due to their ability to maintain and foster widespread and dispersed social connections (Buckingham, 2007; Davis, 2010), significant differences are present as to how youths in these three countries engage with this media form. If for example, comparing the every-day use of SNS, $66 \%$ of Australian youth are doing so compared to $45 \%$ of 13 to 18 -year-olds in the US (Rideout, 2015, p.15). These Australian youth are also far more engaged in the use of visuallycentric social-media forms when compared to UK and US youth. Firstly, if examining agecomparable data from OFCOM (2017) - British youth aged 12 to 15 - with the youth of this study aged 12 to 14, Australian young people utilise Instagram and Snapchat in far higher numbers (67\% vs. $56 \%$ and $54 \%$ vs. $51 \%$ respectively). UK youth, in comparison, make greater 
use of social media platforms that do not lend themselves to the same degree of visuality, i.e. Twitter and Facebook. Whereas one-fifth (20\%) of British youth use Twitter, only one in eight of Australia youth (15\%) does so. When considering engagement with Facebook, differences in the rate of use increases dramatically. In contrast to the $31 \%$ of younger Australians using the oldest of these social media platforms, $82 \%$ of similarly aged British youths use this service. Similarly, if examining data from US young people (Lenhart, 2015), albeit, among those aged 13 to 17, American youth predominately use Facebook (71\%) compared to 52\% of Australians aged 12 to 18 . While the use of Instagram (52\%) and Snapchat (41\%) by US youths is substantially less than among youths of Australia (Instagram 70\% and Snapchat 63\% respectively).

\section{Conclusion}

Information communication technologies are a common feature of the lives of Australian youth. Internet access within the home is near-universal. All bar twelve young people of the 838 completing a usable questionnaire possess at least one form of technology that likely supports Internet access (desktop computer, laptop and tablet). The presence of digital devices within their homes, when compared to young people of the other principle Anglo-nations marks the youth of this study in many respects as being more highly mediated. Findings from these participants also reflect the presence of tangible and measurable reflections on a digital divide. Although households featuring boys and girls are likely to have similar levels of availability to many pieces of technology, substantial variations are present when accounting for technology utilised in pursuit of gaming and consuming digital content. Households with siblings are more likely to be categorised as media-rich, due to the greater availability of technology, when compared to single-child homes. The highest level of completed parental education is another crucial determinate to the quality of the household media experience for youth. This measure is particularly important, as better education tends to equate to higher income levels. National government impetus in the guise of promoting e-learning within schools is also a likely contributor to the construction of the mediated homes of Australian youth.

Gender differences are also present to young peoples' uses of technology in the form of software programs and social media platforms. More girls utilise software supporting creativebased expressive practices such as drawing, writing and making music against boys' preference for technically oriented software reflecting nuances to the ongoing divisions in the media experiences of youth. Likewise, girls utilise social media more than boys, while boys are more avid gamers than girls.

These youth, however, are not "active" media producers despite the ability to create, modify and share content that technological convergence affords. These observations pose essential questions as to how we frame youths" "active" and "passive" uses of media, and whether these distinctions are at all worthwhile within the context of flexibility and spreadability that the digitally convergent media landscape affords.

If to return to the idea of digital nativism, this research helps reaffirm that in some developed nations at least, a digital backdrop helps to contextualise the experience of youth. Importantly, however, the findings of this work highlight that the ubiquity of digital media in the lives of young people is far from a uniform experience. Future research and policy in respect of digital youth must continue to recognise the existence of real impediments to youths' digital participation. Alongside this, as this research makes clear, when there is relative equality to possessing an Internet connection in the home and the digital tools by which to exploit this gender is a clear determinant to how young people use technology and subsequently the digital skills employed with these practices. The orientation of girls toward more creative expressive 
practices against boys' preferences for more technically orientated software would seem indicative of the gender discrepancies found in STEM subjects in further education and employment. More research is required to understand the motivations behind these practices. Because in so doing, we can move beyond the myth of digital nativism and instead look beyond access provisions as a way of understanding digital youth to a more nuanced and rounded approach. As Ragnedda (2017) suggests accounting for how social inequalities such as those related to class, gender, power and status inform access to the Internet, it also determines the exploitation of the Internet and digital technologies.

\section{References}

Australian Bureau of Statistics (2011). Household Use of Information Technology, Australia, 2010-11 (Catalogue number 81460D0002_201011). Retrieved from: www.abs.gov.au/AUSSTATS/subscriber.nsf/log?openagent\&81460DO001_201011.XLS \&8146.0\&Data\%20Cubes\&1B1AA4125BA7789ECA25796600152D23\&0\&2010$11 \& 15.12 .2011 \&$ Previous.

Australian Bureau of Statistics (2017). 2071.0 - Census of Population and Housing: Reflecting Australia - Stories from the Census, 2016. Retrieved from: https://www.abs.gov.au/ausstats/abs@.nsf/Lookup/by\%20Subject/2071.0 2016 Main\%2 0Features Educational\%20Qualifications\%20Data\%20Summary\%20 65.

Australian Communications and Media Authority (ACMA) (2013). Like, Post, Share: Young Australians' Experience of Social Media. Quantitative research report. Retrieved from: https://www.acma.gov.au/-/media/mediacomms/Report/pdf/Like-post-share-YoungAustralians-experience-of-social-media-Quantitative-research-report.pdf?la=en.

Australian Communications and Media Authority (ACMA) (2015). Aussie teens and kids online. Retrieved from: https://www.acma.gov.au/theACMA/engage-blogs/engageblogs/Research-snapshots/Aussie-teens-and-kids-online.

Aries, P. (1973). Centuries of childhood. Harmondsworth: Penguin.

Australian Communications and Media Authority (2008 no.3). Access to the Internet, broadband and mobile phones in family households. Retrieved from: www.acma.gov.au/mediareports.

boyd, d. (2008). Why youth (Heart) social network sites: The role of networked publics in teenage social life. In D. Buckingham (Ed.), MacArthur Foundation series on digital learning - youth, identity, and digital media volume. Cambridge: MIT Press.

boyd, d. \& Hargittai, E. (2013). Connected and concerned: Variations in parents' online safety concerns. Policy \& Internet, 5(3), 245-269. CrossRef

Brand, J., Todhunter, S. and Jervis, J. (2017). Digital Australia 2018. Eveleigh, NSW: IGEA. Retrieved from: http://www.igea.net/wp-content/uploads/2015/07/Digital-Australia2016- DA16-Final.pdf.

Buckingham D. (2000). After the death of childhood: Growing up in the age of electronic media. Cambridge, UK: Polity Press.

Buckingham, D. and Willett, R. (2006). (Eds.). Digital generations: Children, young people, and new media. Mahwah, N.J: Lawrence Erlbaum Associates Inc.

Buckingham, D. (2008). Introducing Identity. Youth, Identity, and Digital Media. (Ed.) David Buckingham. The John D. and Catherine T. MacArthur Foundation Series on Digital Media and Learning. Cambridge, MA: The MIT Press.

Clark, L.S. (2013). The parent app: Understanding families in the digital age. New York: Oxford University Press. 
Cross, B. (2002). Children's stories negotiated identities: Bakhtin and complexity in upper primary classrooms in Jamaica and Scotland, $\mathrm{PhD}$ Thesis: Edinburgh University.

gaspard, 1. (2015). Ecologies of the Televisual: Children's Use of the Televisual in Melbourne, Australia, PhD Thesis, RMIT University.

Green L., Brady D., Ólafsson K, Hartley J. and Lumby, C. (2011). Risks and safety for Australian children on the Internet: Full findings from the AU Kids Online Survey of 9-16 year olds and their parents. Retrieved from: www.ecu.edu.au/_data/assets/pdf_file/0009/294813/U-Kids-Online-Survey.pdf.

Hanrahan ${ }_{2}$ C. (2017) Here's how Australia's schools are funded - and we promise not to mention Gonski. Retrieved from: www.abc.net.au/news/2017-05-30/school-fundingexplained-without-mentioning-gonski/8555276.

Hargittai, E. (2010). Digital na(t)ives? Variation in Internet skills and uses among members of the "net generation". Sociological Inquiry, 80(1), 92-113. CrossRef

Helsper, E.J. (2016) Slipping through the net report: Are disadvantaged young people being further left behind in the digital era? Prince's trust commissioned report. Retrieved from: http://www.lse.ac.uk/media-andcommunications/assets/documents/research/projects/disto/Slipping-through-the-NetDecember-2016.PDF.

Helsper, E. J. and Eynon, R. (2010). Digital natives: where is the evidence? British educational research journal, 36(3), 503-520. CrossRef

Horst, H.A. (2010) Families. In M. Ito (Ed.). (2010). Hanging out, messing around, and geeking out: Kids living and learning with new media. Cambridge, MA; London: MIT Press.

Horst, H.A. (2012). New media technologies in everyday life. In Horst HA and Miller D (Eds.), Digital anthropology. London; New York: Berg.

INNOCA (2016). How is Mobile Technology being adopted by Schools in the UK? Retrieved from: https://www.innovadesigngroup.co.uk/news/how-is-mobile-technology-beingadopted-by-schools-in-the-uk/.

Insight (2015). Fine-Tuning Critical Infrastructures in the Age of Common Core and Online Assessments. Retrieved from:

https://www.insight.com/content/dam/insight- web/en_US/article-

images/whitepapers/Insight-whitepapers/fine-tuning-critical- infrastructures-in-the-ageof-common-core-and-online-assessments.pdf.

Ito, M. (2010). (Ed.) Hanging out, messing around, and geeking out: Kids living and learning with new media. Cambridge, MA; London: MIT Press.

Jenkins, H. (2014). Kids on YouTube: An interview with Patricia Lange (Part One). Retrieved from: www.henryjenkins.org/2014/03/kids-on-youtube-an-interview-with-patricia-langepart-one.html.

Jenkins, H. (2006). Convergence culture: Where old and new media collide. New York; London: New York University Press.

Jenkins, H., Purushotma, R., Weigel, M., Clinton, K., and Robison, A. J. (2009). Confronting the challenges of participatory culture: Media education for the 21st century. Cambridge, MA.: MIT Press.

Jenkins, H., Ford, S. and Green, J. (2013). Spreadable media: Creating value and meaning in a networked culture. New York: NYU Press.

Kaseniemi, E.J. and Rautianen, P. (2002) Mobile culture of children and teenagers in Finland. In Katz J \& Aakhus M (Eds.), Perpetual contact: Mobile communication, private talk, public performance. Cambridge, UK: Cambridge University Press.

Lally, E. (2002) At home with computers. Oxford; New York: Berg. 
Lenhart, A (2015). Teens, social media \& technology overview 2015. Pew Research Center [Internet \& American Life Project].

Livingstone, S. (2002) Young people and new media: Childhood and the changing media environment. London: Sage.

Livingstone, S. and Helsper, E. (2007). Gradations in digital inclusion: Children, young people and the digital divide. New Media \& Society, 9(4), 671-696. CrossRef

McKinsey and Company (1997) The Future of Information Technology in UK Schools. McKinsey and Company, London.

Morley, D. and Silverstone, R. (1990). Domestic communication - Technologies and meanings. Media, Culture and Society, 12(1), 31-55.

OECD (2015). Students, Computers and Learning: Making the Connection, PISA, OECD Publishing. CrossRef

OECD (2019). Education at a Glance 2019: OECD Indicators, OECD Publishing, Paris. CrossRef

OFCOM (2017). Children and parents: Media use and attitudes report 2017. Retrieved from: https://www.ofcom.org.uk/research-and-data/media-literacy-research/childrens/childrenparents-2017.

Palfrey, J.G. and Gasser, U. (2011). Born digital: Understanding the first generation of digital natives. ReadHowYouWant.com.

Project Tomorrow (2013). Schools' Education Technology Budgets Shrink As Need And Demand Grows. Retrieved from: http://www.tomorrow.org/speakup/pr/SU12_April_PR.html.

Promethean World (2016). Attitudes towards technology in education - Promethean Report 2016. Retrieved from: https://resourced.prometheanworld.com/attitudes-prometheanreport-2016/.

Puro, E.J. (2002). Finland: A mobile culture. In Katz JE and Aakhus M (Eds.), Perpetual contact: Mobile communication, private talk, public performance. Cambridge, UK: Cambridge University Press.

Qvortrup, J. (2009a) Macro-sociological studies of childhood: A prologue to a guest issue. In

Qvortrup, J. (2009b). The development of childhood. In Sociological Studies of Children and Youth, 12, 1-26. Emerald Group Publishing Limited.

Qvortrup, J. and Brown Rosier, K.B. and Kinney, D.A. (Eds.) (2009) Structural, historical, and comparative perspectives. Sociological Studies of Children and Youth, Volume 12) (pp. xii-xxiii). Emerald Group Publishing Limited.

Rideout, V. (2015). The Common Sense Census: Media Use by Tweens And Teens. Retrieved from:

https://www.commonsensemedia.org/sites/default/files/uploads/research/census_research report.pdf.

Silverstone, R., Hirsch. E. and Morley, D. (1994). Information and communication technologies and the moral economy of the household. In Silverstone R Hirsch E. (Eds.), Consuming technologies: Media and information in domestic spaces. London: Routledge.

Statista.com (2018). Distribution of computer and video gamers in the United States from 2006 to 2018, by gender. Retrieved from: https://www.statista.com/statistics/232383/gender- split-of-us-computer-and-videogamers/.

Seiter, E. (2005). The Internet playground: Children's access, entertainment and miseducation. New York; Oxford: Peter Lang.

Seiter, E. (2008). Practising at home: Computers, pianos, and cultural capital. In McPherson T (Ed.), Digital youth, innovation, and the unexpected (The John D. and Catherine T. 
Macarthur Foundation series on digital media and learning). Cambridge, Mass: MIT Press.

Statista.com (2018). Age breakdown of video game players in the United States in 2018. Retrieved from: https://www.statista.com/statistics/189582/age-of-us-video-gameplayers-since-2010/.

Statista.com (2019a). Games console usage among children in the United Kingdom (UK) 2013- 2018, by age. Retrieved from; https://www.statista.com/statistics/274418/use-ofgames- consoles-and-players-among-children-in-the-uk-by-age/.

Statista.com (2019a). Age breakdown of video gamers in the United Kingdom (UK) in 2014. Retrieved from: https://www-statista-com.ezp.lib.unimelb.edu.au/statistics/240751/agebreakdown-of-gamers-in-the-uk/.

Süss, D., Suoninen, A., Garitaonandia, C., Juaristi, P., Kokkalainen and Olega, J.A. (2001). Media childhood in three European countries. In Hutchby I and Moran-Ellis J(2001) (Eds.). Children, technology and culture: The impacts of technologies in children's everyday lives. Oxon: RoutledgeFalmer.

Tapscott, D. (2009). Growing up digital: The rise of the net generation. New York: McGraw Hill.

Tufte, B. and Rasmussen, J. (2010). Children and the Internet. In D. Marshall (Ed.), Understanding children as consumers. London: SAGE Publications Ltd.

Tripp, L.M. (2010). "The computer is not for looking around, it is for school work": Challenges for digital inclusion as La no immigrant families negotiate children's access to the Internet. New Media \& Society, 13(4), 552-567. CrossRef

Victoria State Government (2019). Summary Statistics for Victorian Schools July 2019. Retrieved from:

https://www.education.vic.gov.au/Documents/about/department/brochurejuly.pdf. 